\title{
PERAN IBU DALAM BERKOMUNIKASI DAN PENGELOLAAN KEUANGAN RUMAH TANGGA
}

\author{
Jurica Lucyanda ${ }^{1 *}$, Eli Jamilah Mihardja ${ }^{2}$, Adi Budi Priyanto ${ }^{3}$ \\ ${ }^{1}$ Program Studi Akuntansi, ${ }^{2}$ Program Studi Ilmu Komunikasi, Fakultas Ekonomi dan Ilmu Sosial, \\ ${ }^{3}$ Program Studi Teknik Industri, Fakultas Teknik dan Ilmu Komputer. Universitas Bakrie, Indonesia \\ E-mail: 1jurica.lucyanda@bakrie.ac.id*,2eli.mihardja@bakrie.ac.id, 3adi.budipriyanto@bakrie.ac.id
}

Received: February 18, 2020 / Revised: June 23, 2020 / Accepted: June 30, 2020

DOI: https://doi.org/ 10.36782/ijsr.v2i1.22

\begin{abstract}
ABSTRAK
Kegiatan pengabdian masyarakat ini bertujuan untuk memberikan penjelasan dan pemahaman terkait dengan peran ibu rumah tangga sebagai manajer keluarga dalam berkomunikasi dan pengelolaan keuangan didalam keluarga. Tujuan kegiatan ini secara khusus adalah agar ibu-ibu di Desa Kejapanan Kecamatan Gempol, Kabupaten Pasuruan Jawa Timur dapat menerapkan komunikasi keluarga secara efektif dan terampil dalam mengelola keuangan dan membuat laporan keuangan sederhana. Mitra kegiatan pengabdian kepada masyarakat ini adalah ibu-ibu rumah tangga (kelompok perempuan) di Desa Kejapanan, kecamatan Gempol, Kabupaten Pasuruan Jawa Timur. Metode yang digunakan dalam kegiatan ini adalah pemaparan materi terkait dengan bagaimana komunikasi yang baik dengan keluarga dan pengelolaan keuangan rumah tangga dan dilanjutkan dengan diskusi/tanya jawab. Peserta ibu rumah tangga yang mengikuti kegiatan ini sebanyak 20 orang. Pelaksanaan kegiatan ini memberikan pemahaman dan memotivasi ibu rumah tangga untuk melakukan komunikasi yang baik untuk membangun kedekatan anggota keluarga dan melakukan pencatatan keuangan sederhana sebagai sarana untuk mengendalikan keuangan keluarga. Hal ini ditunjukkan dari antusiasnya ibu rumah tangga dalam diskusi dan bertanya terkait dengan pengelolaan keuangan rumah tangga. Kegiatan pengabdian ini diharapkan menjadi kegiatan lanjutan untuk dijadikan desa binaan Universitas Bakrie untuk memulai bisnis kecil dalam rangka untuk meningkatkan pendapatan rumah tangga sesuai dengan kondisi yang ada di daerah mereka.
\end{abstract}

Kata kunci: komunikasi keluarga, manajer keluarga, mengelola keuangan keluarga, peran ibu rumah tangga

\begin{abstract}
This community service activity aims to provide an explanation and understanding related to the role of housewives as family managers in communicating and managing financial within the family. The special purpose of this activity is that mothers in Desa Kejapanan, Gempol, Pasuruan, Jawa Timur, can implement family communication effectively and skillfully in managing finances and making simple financial reports. The community service partners are housewives (women's groups) in Desa Kejapanan, Kecamatan Gempol, Kabupaten Pasuruan, Jawa Timur. The method used in this activity is the presentation of material and discussion/question and answer. Participants of housewives who participated in this activity were 20 people. The implementation
\end{abstract}


of this activity provides understanding and motivates housewives to have good communication to build the closeness of family members and conduct simple financial records to controlling family finances. This is shown from the enthusiasm of housewives in discussions and questions related to household financial management. This community service is expected to be a followup activity to become a fostered village by the University of Bakrie to start a small business in order to increase household income in accordance with the condition in their area.

Keywords: family communication, family manager, managing family finances, the role of housewives.

\section{PENDAHULUAN}

Keluarga merupakan unit sosial terkecil di dalam masyarakat yang terdiri dari ayah, ibu dan anak-anak yang belum menikah (Trisnaningsih \& Widyasari, 2010). Dalam budaya Indonesia terkait dengan keluarga pada umumnya melakukan pembagian tugas antar suami dan istri, dimana suami bertugas mencari nafkah sekaligus memberikan perlindungan anggota keluarga, sedangkan ibu memegang peranan sebagai pengatur (manajer) keluarga atau rumah tangga 1 temasuk cara berkomunikasi, mengelola keuangan dan mendidik anak-anak.

Komunikasi dalam keluarga merupakan momen penting untuk membentuk identitas diri remaja, maka perlu ditingkatkan intensitas komunikasi dalam keluarga. Selain berkomunikasi dengan baik dalam keluarga, mengelola keuangan keluarga juga merupakan suatu kegiatan penting dalam rumah tangga. Mengelola keuangan keluarga merupakan bagian dari perencanaan keuangan, dimana perencanaan keuangan tidak hanya untuk perusahaan saja tapi dalam suatu keluarga sangat perlu untuk melakukan perencanaan keuangan keluarga.

Komunikasi keluarga merupakan bentuk pengorganisasian yang menggunakan kata-kata, sikap tubuh (gesture), intonasi suara, tindakan untuk menciptakan harapan image, ungkapan perasaan serta saling membagi pengertian (Badan Kependudukan \& Keluarga Berencana Nasional, 2008). Keterkaitan antar anggota keluarga berhubungan dengan proses komunikasi. Fokus dari penelitian mengenai sistem keluarga bukan hanya pada masingmasing individu namun pada hubungan antar anggota keluarga karena komunikasi merupakan proses simbolik dan transaksional dari pertukaran makna (Galvin, Bylund \& Brommel, 2004). Hubungan dibangun, diatur, dan berubah dengan interaksi yang dikomunikasikan antar anggota (Duncan \& Rock 1993 dalam Galvin, Bylund \& Brommel, 2004). Berdasarkan penjelasan tersebut maka perlu memfokuskan

\footnotetext{
${ }^{1}$ Dalam artikel ini keluarga dan rumah tangga adalah istilah yang dapat dipertukarkan.
} 
komunikasi untuk memperkuat hubungan antar anggota keluarga, bukan hanya pada anggota keluarga secara individual.

Terdapat beberapa alasan mengapa keluarga memerlukan perencanaan keuangan (Senduk, 2000). Pertama, adanya tujuan keuangan yang ingin dicapai. Kedua, naiknya biaya hidup dari tahun ketahun sehingga menyebabkan tingginya biaya hidup saat ini, hal ini disebabkan tingkat inflasi yang tinggi. Ketiga, keadaan perekenomian yang tidak pasti. Keempat, fisik manusia yang tidak selalu sehat, sehingga perlu ada uang cadangan untuk biaya kesehatan. Kelima, banyaknya alternatif produk keuangan.

Untuk merencanakan dan mengelola keuangan yang maksimal dan optimal, ada beberapa hal yang perlu dilakukan oleh ibu rumah tangga yaitu: (1) menetapkan tujuan keuangan yang terukur; (2) evaluasi keuangan secara periodik; (3) perencanaan sedini mungkin; dan (4) penetapan tujuan keuangan harus realistis (Trisnaningsih \& Widyasari, 2010). Hal ini merupakan tugas ibu rumah tangga sebagai manajer keluarga untuk mengelola keuangan rumah tangga dengan baik. Namun, pada umumnya ibu rumah tangga ini enggan melakukan pengelolaan keuangan rumah tangga karena merasa suatu perkerjaan yang rumit. Keengganan ibu rumah tangga untuk melakukan pengelolaan keuangan rumah tangga kemungkinan disebabkan oleh faktor pendidikan. Pengetahuan tentang pengelolaan keuangan keluarga bukan hanya karena kebiasaan atau faktor lingkungan, tapi dipengaruhi oleh pendidikan formal.

Mitra kegiatan pengabdian kepada masyarakat ini adalah ibu rumah tangga (kelompok perempuan) di Desa Kejapanan, Kecamatan Gempol, Kabupaten Pasuruan Jawa Timur. Ibu rumah tangga di Desa Kejapanan ini umumnya adalah ibu rumah tangga dengan pendidikan sekolah yang tidak tinggi. Selain itu ibu rumah tangga ini hanya mengandalkan sumber keuangan dari suami sebagai keluarga. Sehingga mereka membutuhkan suatu edukasi yang simple terkait pengelolan keuangan rumah tangga untuk memberikan motivasi dan pemahaman untuk menyelesaikan atau memberikan alternatif solusi untuk mengatasi dinamika perkembangan sosial.

Berdasarkan permasalahan tersebut, maka perlu diadakan kegiatan pelatihan bagi ibu rumah tangga agar mereka dapat memaksimalkan peran mereka sebagai manajer rumah tangga. Program pelatihan berupa pelatihan pengelolaan keuangan rumah tangga dan komunikasi dalam keluarga. Pelatihan pengelolaan keuangan yang diberikan dalam bentuk mengajarkan akuntansi sederhana yang disesuaikan dengan skala rumah tangga. Sedangkan pelatihan komunikasi dalam bentuk memberikan pengetahuan cara interaksi dengan komunikasi yang baik dalam keluarga.

Kegiatan pengabdian masyarakat ini bertujuan untuk memberikan penjelasan dan pemahaman terkait dengan peran ibu rumah 
tangga dalam berkomunikasi dan pengelolaan keuangan didalam keluarga. Pelatihan ini diharapkan para ibu rumah tangga dapat menaksimalkan peran mereka sebagai manajer rumah tangga.

Pemilihan lokasi Pengabdian kepada Masyarakat (PkM) ini didasarkan pada alasanalasan sosial kemasyarakatan. Hal ini sesuai dengan tujuan kegiatan PkM secara umum. Pemilihan lokasi kegiatan pengabdian ini mempertimbangkan beberapa hal. Pertama, silaturahmi dengan keluarga dosen Universitas Bakrie dan dalam rangka memperkuat team bonding di kalangan dosen dan karyawan Universitas Bakrie. Kedua, memperluas wawasan dan jaringan kerjasama dengan pihak-pihak terkait di seluruh Indonesia umumnya dan di Jawa khususnya. Ketiga, memperkenalkan dan menyosialisasikan nama Universitas Bakrie ke wilayah cakupan yang lebih luas dengan harapan mendapatkan awareness dan citra yang lebih baik yang juga akan bermanfaat untuk memperluas jangkauan promosi dan admisi Universitas Bakrie. Terakhir, memberikan sumbangan kepakaran dari dosen Universitas Bakrie kepada masyarakat luas dengan cakupan yang lebih luas daripada wilayah Jabodetabek.

\section{TINJAUAN PUSTAKA}

\section{Akuntansi Rumah Tangga}

Akuntansi suatu sistem informasi yang menyediakan laporan untuk para pemangku kepentingan mengenai aktivitas ekonomi dan kondisi perusahaan (Warren, Reeve, \& Duchac 2013). Secara sederhana pengertian akuntansi adalah suatu aktivitas atau proses dalam mengidentifikasi, mencatat, mengklasifikasi, mengolah dan menyajikan data yang berhubungan dengan keuangan atau transaksi agar mudah dimengerti dalam mengambil keputusan yang tepat.

Akuntansi rumah tangga adalah suatu kegiatan melakukan pencatatan terhadap pemasukan dan pengeluaran rumah tangga dalam periode tertentu, biasanya dilakukan secara bulanan. Akuntansi rumah tangga adalah sesuatu yang mudah untuk dipelajari namun seringkali tidak diterapkan dalam rumah tangga. Keengganan menerapkan akuntansi rumah tangga bukan karena mengalami kesulitan menggunakan metode dan prinsip pencatatannya, tetapi karena dari keengganan keluarga untuk menerapkannya. Selama ini umumnya akuntansi rumah tangga dianggap suatu hal yang sepele oleh ibu rumah tangga sehingga berkecenderungan mengabaikannya. Padahal banyak manfaat yang didapat dengan menerapkan akuntansi rumah tangga. Keluarga dapat mengetahui pos-pos pengeluaran mana yang dianggap tidak perlu, sehingga kedepannya mereka dapat lebih berhati-hati dalam mengelola keuangan dan berhemat. Akuntansi rumah tangga sangat diperlukan oleh keluarga untuk mengelola keuangan keluarga. 


\section{Mengelola Keuangan Keluarga}

Gozali (2002) menjelaskan mengelola keuangan keluarga menjadi perhatian penting dalam menentukan tingkat kemakmuran ekonomi sebuah keluarga. Pengelolaan keuangan yang dimaksud adalah perencanaan keuangan. Lebih lanjut Gozali (2002) menjelaskan bahwa perencanaan keuangan yang baik adalah yang membuat daftar pemasukan dan pengeluaran uang secara terperinci. Dengan adanya daftar yang terperinci, ibu rumah tangga sebagai manager keuangan keluarga dapat mendeteksi dan mengawasi setiap terjadi penyimpangan rencana keuangan.

Menurut Goss (2001), penyebab utama terjadinya penyimpangan perencanaan keuangan adalah kelemahan dalam membedakan antara "Kebutuhan" dan "Keinginan". Pengeluaran uang untuk "Kebutuhan" sifatnya wajib karena terkait langsung dengan kebutuhan pokok keluarga, sementara pengeluaran uang untuk "Keinginan" sifatnya tidak wajib sehingga hanya akan dikeluarkan pada saat-saat tertentu.

Untuk dapat mengelola keuangan keluarga perlu beberapa kiat yang harus diterapkan, sehingga tujuan dari mengelola keuangan keluarga tersebut tercapai (Trisnaningsih \& Widyasari, 2010). Pertama, membuat daftar pengeluaran setiap bulan baik pengeluaran kebutuhan dan keinginan rutin dan non-rutin. Kedua, membahas empat kelompok pengeluaran tersebut dengan pasangan (suami). Ketiga, setelah ada daftar penerimaan uang dan pengeluaran uang, maka keluarga bisa mengetahui seberapa besar sisa kas yang miliki setiap bulannya. Keempat, langkah terakhir yang harus lakukan adalah memantau hasil rencana keuangan dalam periode tertentu secara rutin. Pemantauan ini dilakukan untuk memastikan bahwa rencana keuangan berjalan sesuai dengan tujuan keluarga.

Perencanaan keuangan keluarga tidak hanya diperuntukkan bagi mereka yang berpendapatan besar (Yohnson, 2004). Setiap orang baik kaya atau miskin perlu untuk membuat perencanaan hidupnya guna mewujudkan tujuan hidupnya, namun yang berbeda hanyalah dalam pengalokasian pengelolahan uang.

\section{Peran Ibu dalam Komunikasi Keluarga}

Keluarga merupakan kelompok sosial pertama dalam kehidupan manusia dimana ia belajar dan menyatakan diri sebagai manusia sosial, dalam interaksi dengan kelompoknya. (Kurniadi, 2001). Dalam keluarga yang sesungguhnya, komunikasi merupakan sesuatu yang harus dibina, sehingga anggota keluarga merasakan ikatan yang dalam serta saling membutuhkan. Dalam keluarga, seorang ibu biasanya lebih intensif dalam berkomunikasi dalam keluarga di bandingkan sang ayah yang lebih sering berada di luar rumah untuk mencari nafkah demi memenuhi kebutuhan keluarga.

Komunikasi dalam keluarga juga dapat diartikan sebagai kesiapan membicarakan 
dengan terbuka setiap hal dalam keluarga baik yang menyenangkan maupun yang tidak menyenangkan, juga siap menyelesaikan masalah-masalah dalam keluarga dengan pembicaraan yang dijalani dalam kesabaran dan kejujuran serta keterbukaan (Friendly, 2002). Komunikasi antarpribadi dalam kehidupan keluarga merupakan proses pengiriman dan penerimaan pesan di antara anggota keluarga dengan berbagai efek dan umpan balik. Dalam penelitian yang telah dilakukan, dikemukakan bahwa anak/remaja yang dibesarkan dalam lingkungan sosial keluarga yang tidak baik/disharmoni keluarga, maka resiko anak untuk mengalami gangguan kpribadian menjadi berkepribadian antisosial dan berperilaku menyimpang lebih besar dibandingkan dengan anak/remaja yang dibesarkan dalam keluarga sehat/harmonis (sakinah).

Keterkaitan antar anggota keluarga berhubungan dengan proses komunikasi. Fokus dari penelitian mengenai sistem keluarga bukan hanya pada masing-masing individu namun pada hubungan antar anggota keluarga karena komunikasi merupakan proses simbolik dan transaksional dari pertukaran makna (Galvin, Bylund, \& Brommel, 2004). Hubungan dibangun, diatur, dan berubah dengan interaksi yang dikomunikasikan antar anggota (Duncan \& Rock 1993, dalam Galvin, et al., 2004). Berdasarkan penjelasan tersebut maka penelitian ini memfokuskan pada hubungan antar anggota keluarga, bukan hanya pada anggota keluarga secara individual.

Keluarga memiliki fungsi-fungsi peran yang dimainkan oleh masing-masing anggota keluarga. Peran dibangun dalam sebuah keluarga, berkembang dengan cara berkomunikasi seperti berdiskusi, berdialog, dan bernegosiasi antar anggota keluarga (Galvin et al., 2004). Berdasarkan penjelasan tersebut, terlihat bahwa peran keluarga dan aturan-aturan berkomunikasi pada suatu keluarga merupakan dua hal yang saling berkaitan dan saling mempengaruhi.

Komunikasi merupakan pusat dari keluarga dan fungsinya (Poire, 2006). Komunikasi dalam keluarga salah satunya terlihat dalam permainan peran oleh anggota keluarga. Peran yang dipegang oleh anggota keluarga dinegosiasikan melalui komunikasi. Teori peran mengasumsikan bahwa peran yang dipegang oleh seseorang merupakan diktator bagi perilaku yang dijalankan (Poire, 2006). Asumsi ini berarti bahwa peran yang dipegang salah seorang anggota keluarga akan mempengaruhi perilaku yang akan dilakukan oleh anggota keluarga tersebut. Misalnya, seorang anggota keluarga yang memegang peran sebagai ayah akan berperilaku sebagai ayah yaitu menyediakan kebutuhan dasar, mengasuh, dan lain sebagainya. Peran pada keluarga merupakan pola perilaku berulang yang berkembang melalui interaksi yang digunakan oleh para anggota keluarga untuk memenuhi fungsi keluarga (Galvin et al., 2004). Peran-peran yang dijalankan dalam keluarga 
tersebut menyeimbangkan jalannya sistem keluarga (Galvin et al., 2004). Peran-peran tersebut akan diteliti pada anggota keluarga yang memiliki individu penyandang autisme. Menurut Galvin et al. (2004) fungsi-fungsi peran pada keluarga di antaranya adalah sosialisasi gender, pengasuhan dan dukungan, pengembangan individu, pemeliharaan kekerabatan, serta penyedia sumber daya dasar. Peran ini yang akan dibahas terkait dengan peran ibu dalam komunikasi keluarga.

Salah satu peran domestik perempuan dalam keluarga adalah pola pengasuhan anak (Peck, 1993). Pola asuh anak dalam keluarga juga berkaitan erat dengan pola komunikasi dan relasi gender antara laki- laki dan perempuan di dalamnya. Pada keluarga-keluarga yang tanggung jawab ekonominya sepenuhnya dilakukan oleh ayah (suami), peran ibu dalam mengasuh anak-anak sangatlah dominan. Pada kasus semacam ini, ibu berperan penuh dalam sektor domestik dan ayah hanya mengurusi sektor produktif yang berkaitan dengan pemenuhan kebutuhan materi keluarga tersebut. Pola pengasuhan yang diterapkan akan berbeda jika dalam sebuah keluarga ibu juga ikut mengurusi sektor produktif dan sektor domestik sekaligus atau yang disebut mengalami peran ganda.

Pergeseran nilai-nilai sosial budaya dimana banyak perempuan yang kemudian turut terlibat dalam pemenuhan kebutuhan ekonomi keluarga dan lebih banyak menghabiskan waktu di luar rumah mengakibatkan berkurangnya kualitas pola asuh terhadap sang anak (Hadisubrata, 1990). Disisi lain sosok ayah belum tentu telah siap menggantikan ataupun membantu peran ibu dalam mengasuh anak baik dari segi psikologis, fisioligis maupun sosial. Dalam situasi demikian untuk memenuhi kebutuhan pengasuhan anak muncullah sosok-sosok yang lain seperti kakek, nenek, kakak, saudara, bahkan mungkin seorang pengasuh anak profesional (babysitter) yang berfungsi sebagai alternative care bagi anak. Namun demikian sosok pengasuh ini dalam banyak hal kenyataannya tidak sebaik apabila pengasuhan dilakukan oleh orang tua kandung.

Intensitas komunikasi masih sering dilakukan antara orang tua, anak, kakak/adik dan keluarga yang tinggal serumah. Tingkat keharmonisan dalam keluarga masih terasa, walaupun harus diakui tetap ada konflik internal namun masih teratasi dengan komunikasi. Komunikasi dalam keluarga sangat penting untuk membentuk identitas diri remaja. Oleh karena itu, perlu ditingkatkan intensitas komunikasi dalam keluarga.

\section{METODA KEGIATAN}

Kegiatan ini merupakan program penyuluhan atau pelatihan berupa penyampaian materi untuk pengembangan ilmu, disampaikan oleh para dosen dengan didampingi mahasiswa yang kompeten dalam bidang akuntansi, komunikasi dan manajemen.

Mitra kegiatan pengabdian kepada 
masyarakat ini adalah ibu-ibu rumah tangga (kelompok perempuan) di Desa Kejapanan, Kecamatan Gempol, Kabupaten Pasuruan Jawa Timur. Peserta yang mengikuti kegiatan ini sebanyak 20 orang.

Metoda kegiatan ini dilaksana dalam dua sesi. Pertama, pemaparan materi terkait pengelolaan keuangan keluarga. Selain menjelaskan materi, peserta diberikan forokopi materi supaya dapat disimpan jika dibutuhkan sebagai referensi. Kedua, melakukan diskusi dan tanya-jawab terkait dengan materi yang telah dipaparkan. Ibu-ibu peserta Sangat antusias bertanya terkait pengelolaan keuangan dan akuntansi rumah tangga.

\section{HASIL DAN PEMBAHASAN}

\section{Profil Masyarakat Desa}

Kejapanan merupakan salah satu desa di Kecamatan Gempol, Kabupaten Pasuruan, Jawa Timur. Kejapanan berbatasan langsung dengan Desa Karangrejo di selatan, Desa Legok di timur, Desa Gempol di utara, dan Desa Carat di barat. Luas wilayah \pm 626 hektar, terdiri atas 12 dusun, 27 RW dan 135 RT, serta jumlah penduduk 21.713 jiwa.

Kabupaten Pasuruan memiliki beragam potensi, mulai dari alam, budaya, hingga geliat perekonomian masyarakat, khususnya makanan dan minuman. Hampir di semua kecamatan memiliki produk khasnya masing-masing. Di daerah ini terdapat beberapa usaha UKM yang memproduksi makanan "Bakpia". Daerah ini terkenal dengan bakpia yang beragam rasa dan harga. Sehingga daerah ini dikenal dengan kampong bakpia dan sering dikunjungi pendatang untuk membeli oleh-oleh.

Secara keseluruhan peserta kegiatan Pengabdian kepada Masyarakat Universitas Bakrie adalah ibu-ibu (kelompok perempuan) warga Desa Kejapanan Kecamatan Gempol Kabupaten Pasuruan Jawa Timur. Peserta ibu rumah tangga yang mengikuti kegiatan ini memiliki rentang usia 25 sampai 70 tahun, jumlah peserta terdiri dari 20 orang. Secara umum peserta merespons dengan antusias adanya kegiatan pengabdian ini. Peserta mengikuti pemberian materi dan mengikuti kegiatan sesi tanya jawab (interaksi dengan pemateri) dengan antusias dan semangat. Gambar 3 menjelaskan para peserta kegiatan dan pelaksanaan kegiatan.
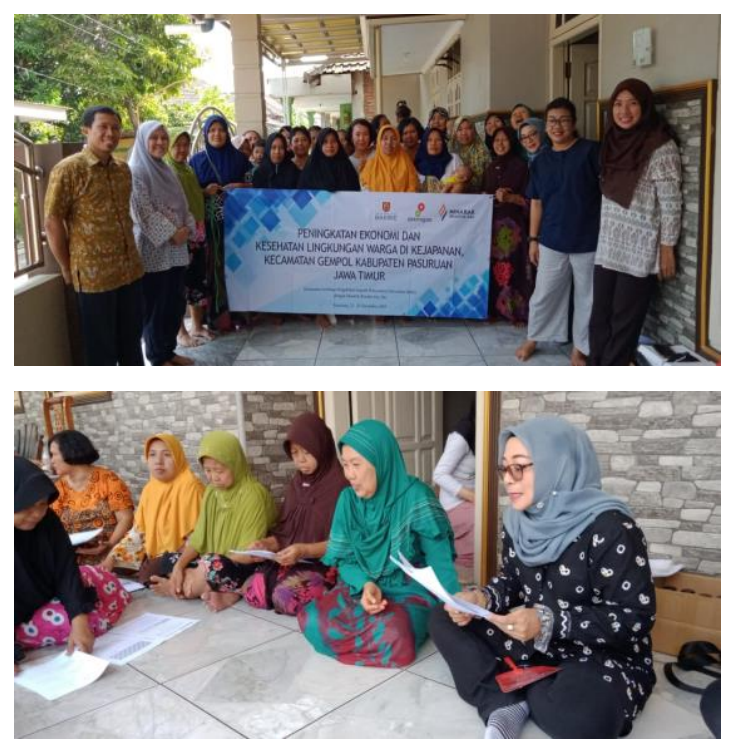

Gambar 1. Peserta Kegiatan dan Pelaksanaan Kegiatan

(Sumber: dokumentasi penulis) 


\section{PEMBAHASAN KEGIATAN}

Dalam rumah tangga atau keluarga, ibu memegang peranan sebagai pengatur rumah tangga termasuk dalam mengelola uang dan mendidik anak-anak. Sehingga hal ini yang menjadi motivasi kegiatan ini dilakukan agar ibu secara maksimal dapat menjalankan perannya tersebut. Mengelola keuangan keluarga merupakan tanggung jawab ibu sebagai manajer keluarga. Mengelola keuangan keluarga sebenarnya bukanlah suatu suatu aktivitas yang sulit dilakukan. Namun pada umumnya adalah keengganan ibu-ibu melakukan pencatatan saja. Secara sederhana pencatatan setiap penerimaan dan pengeluaran setiap uang adalah suatu pengelolaan keuangan keluarga. Pencatatan tersebut dalam istilah keuangan dinamakan akuntansi, karena ini adalah level keluarga atau rumah tangga, maka disebut akuntansi rumah tangga dengan cakupan yang kecil.

Kegiatan ini dilakukan dalam bentuk pemberian materi terkait dengan cara komunikasi keluarga yang baik dan pengelolaan keuangan keluarga. Setelah pemberian materi, ibu-ibu diberikan kesempatan untuk bertanya terkait dengan materi yang diberikan. Materi pertama diberikan dengan menjelaskan apa yang dimaksud dengan akuntansi rumah tangga. Akuntansi rumah tangga merupakan suatu kegiatan pencatatan terhadap pemasukan dan pengeluaran rumah tangga dalam periode tertentu, biasanya dilakukan secara bulanan. Dari hasil penjelasan dan diskusi dengan ibu rumah tangga terkait dengan akuntansi rumah tangga disimpulkan bahwa akuntansi rumah tangga adalah sesuatu yang mudah untuk dilakukan namun seringkali tidak diterapkan dalam rumah tangga. Menurut ibu rumah tangga bahwa tidak diterapkan akuntansi rumah tangga tersebut karena adanya keengganan ibu-ibu dalam melakukan pencatatan. Keenggan tersebut bukan karena mengalami kesulitan menggunakan metode dan prinsip pencatatannya, tetapi karena malas melakukan pencatatan penerimaan dan pengeluaran keuangan keluarga saja. Umumnya akuntansi rumah tangga dianggap suatu hal yang sepele sehingga banyak ibu rumah tangga mengabaikannya. Padahal banyak manfaat yang didapat dengan menerapkan akuntansi rumah tangga. Keluarga dapat mengetahui pos-pos pengeluaran mana yang dianggap tidak perlu, sehingga kedepannya mereka dapat lebih berhati-hati dalam mengelola keuangan dan berhemat. Akuntansi rumah tangga sangat diperlukan oleh keluarga untuk mengelola keuangan keluarga.

Selain menjelaskan definisi akuntansi rumah tangga, mafaat dan bentuk akuntansi rumah tangga, pemateri memberikan contoh bagaimana membuat pencatatan sederhana untuk akuntansi rumah tangga. Tabel 3 merupakan contoh akuntansi rumah tangga dengan melakukan pencatatan penerimaan dan pengeluaran uang keluarga dalam periode tertentu. 
Tabel 1. Contoh Akuntansi Rumah Tangga: Pencatatan Kas Masuk (Penerimaan) dan Kas Keluar (Pengeluaran)

\begin{tabular}{|c|c|c|c|c|c|}
\hline No & $\begin{array}{c}\text { Tangga } \\
\text { I 11/ } \\
2019 \\
\end{array}$ & $\begin{array}{c}\text { Keterang- } \\
\text { an }\end{array}$ & $\begin{array}{c}\text { Peneri- } \\
\text { maan } \\
(000)\end{array}$ & $\begin{array}{l}\text { Pengelua } \\
\text { r-an (000) }\end{array}$ & $\begin{array}{c}\text { Saldo } \\
\text { (Rp) } \\
(000)\end{array}$ \\
\hline \multirow[t]{2}{*}{1.} & 1 & Gaji & 2.00 & & 2.00 \\
\hline & & & 0 & & 0 \\
\hline \multirow[t]{3}{*}{2.} & 2 & Bayar & & 100 & 1.90 \\
\hline & & Uang & & & 0 \\
\hline & & Sekolah & & & \\
\hline \multirow[t]{3}{*}{3.} & 4 & Cicilan & & 100 & 800 \\
\hline & & Panci & & & \\
\hline & & $(2)$ & & & \\
\hline \multirow[t]{10}{*}{4.} & & Beras & & 100 & 750 \\
\hline & & dan & & & \\
\hline & & Kebutu & & & \\
\hline & & han & & & \\
\hline & & Rumah & & & \\
\hline & & di & & & \\
\hline & & Warung & & & \\
\hline & & Dan & & & \\
\hline & & seterus & & & \\
\hline & & -nya... & & & \\
\hline
\end{tabular}

Selain itu dijelaskan juga bagaimana pentingnya membuat perencanaan keuangan keluarga sehingga uang yang dimiliki keluarga dapat dikelola dengan baik. Mulai dari membuat daftar kebutuhan yang sifatnya rutin dan dengan kebutuhan yang tidak rutin. Ibu-ibu juga harus dapat membedakan antara "Kebutuhan" dengan "Keinginan". "Kebutuhan" sifatnya wajib karena terkait langsung dengan kebutuhan pokok keluarga, sementara pengeluaran uang untuk "Keinginan" sifatnya tidak wajib sehingga hanya akan dikeluarkan pada saat-saat tertentu.

Secara umum, ibu-ibu memiliki keinginan untuk menerapkan akuntansi rumah tangga sehingga memudahkan ibu-ibu untuk memonitor penerimaan dan pengeluaran uang keluarga mereka. Dalam kegiatan ini ibu-ibu juga memiliki keinginan untuk dapat mempunyai kegiatan kecil yang dapat menghasilkan uang sebagai tambahan uang keluarga. Kegiatan selanjutnya mungkin perlu dilakukan untuk memberikan perlatihan kepada ibu-ibu untuk memanfaatkan waktu dengan melakukan bisnis kecil-kecilan yang dapat memberikan tambahan uang untuk keluarga mereka.

\section{KESIMPULAN DAN SARAN}

Berdasarkan evaluasi hasil dari pelaksanaan kegiatan Pengabdian kepada Masyarakat terkait pelatihan komunikasi dan keuangan keluarga dalam perspektif rumah tangga menunjukkan semangat dan antusiasme ibu-ibu Desa Kepajanan, Gempol, Pasuruan, Jawa Timur dalam mengikuti kegiatan ini. Kegiatan Pengabdian kepada Masyarakat ini diharapkan berkontribusi dalam penambahan pengetahuan dibidang ilmu komunikasi dan akuntansi khususnya bagaimana cara komunikasi yang efektif dalam keluarga dan mengelola keuangan keluarga yang efisien. Selain itu juga berdampak pada pengetahuan tentang pengelolaan keuangan keluarga khususnya dalam bidang pencatatan keuangan secara sederhana.

Dari hasil kegiatan ini dapat disimpulkan bahwa bahwa ibu rumah Desa Kepajanan dapat dan mampu menyerap ilmu yang diberikan. Ibuibu di desa ini berjanji akan menerapkan sesuai dengan konsep yang diberikan dan melakukan pencatatan keuangan sederhana sebagai sarana 
untuk mengendalikan keuangan keluarga. Dengan mengaplikasikan pengelolaan komunikasi serta pengelolaan keuangan keluarga, diharapkan warga khususnya ibu-ibu Desa Kepajanan, Gempol, Pasuruan, Jawa Timur dapat melakukan tugas dan peran menjadi manajer rumah tangga yang dapat menjalankan komunikasi keluarga dan mengelola keuangan keluarga dalam rumah tangga mereka.

Berdasarkan dari hasil kegiatan Pengabdian kepada Masyarakat di Desa Kepajanan, Gempol, Pasuruan, Jawa Timur, maka saran yang dapat diberikan untuk kegiatan selanjutnya agar ditindak lanjuti berupa kegiatan lanjutan pengabdian kepada masyarakat yaitu untuk dijadikan desa binaan Universitas Bakrie untuk memulai bisnis kecil dalam rangka untuk meningkatkan pendapatan rumah tangga sesuai dengan hasil yang ada di daerah mereka. Hal ini disarankan, karena dapat mensejahterakan perekonomian warga khususnya ibu rumah tangga di Desa Kepajanan, Gempol, Pasuruan, Jawa Timur.

\section{UCAPAN TERIMA KASIH}

Kegiatan ini terselenggara atas bantuan dan kerjasama dari Lembaga Pengabdian kepada Masyarakat Universitas Bakrie. Kami mengucapkan terima kasih kepada Lembaga Pengabdian kepada Masyarakat Universitas Bakrie yang telah mendanai dan memfasilitasi kegiatan pengabdian ini.

\section{DAFTAR PUSTAKA}

Badan Kependudukan \& Keluarga Berencana Nasional. (2008). Buku Panduang Pusat Informasi dan Konseling Kesehatan Reproduksi Remaja (PIK KRR). Jakarta: BKKBN. Friendly. (2002). Komunikasi dalam Keluarga. Jakarta: Family Altar.

Galvin, K. M., Bylund, C., \& Brommel, B. J. (2004). Family Communication: Cohesion and Change. Taylor \& Francis Group.

Goss, B. J. D. (2001). 11 Top Financial Planning Mistakes and How to Avoid Them. Chiropractic Economic. Chiropractic Economics. Diakses dari www.chiroeco.com/ article/investments/financial-planningmista ke

Gozali, (2002). Rencana Keuangan Keluarga, Seberapa Perlukah. Diakses dari http://www.perencanakeuangan.com.

Hadisubrata. (1990). Keluarga Dalam Dunia Modern. Jakarta: PT. BPK Gunung Mulia.

Kurniadi, O. (2001). Pengaruh komunikasi keluarga terhadap prestasi belajar anak. Mediator: Jurnal Komunikasi, 2(2), 267-290.

Le Poire, B. A. (2006). Family Communication: Nurturing and Control in a Changing World. SAGE Publications, Inc.

Peck, J. C. (1993). Wanita dan Keluarga. Yogyakarta: Kanisius.

Senduk, S. (2000). Mengelola Keuangan Keluarga. Jakarta: PT. Alex Media Komputindo. 
Indonesian Journal for Social Responsibility (IJSR) Vol. 2, No. 01, (2020), hal. 47-58

Trinaningsih, S. \& Widyasari, F. (2010). Yohnson. (2004). Peran Universitas di Surabaya Manajemen Pengelolaan dan Perencanaan dalam Meningkatkan Jumlah Keluarga Keuangan Keluarga pada Ibu Rumah Tangga Mapan di Surabaya: Seri Penelitian di Kawasan Siwalan Kerto Surabaya. Jurnal Keuangan Keluarga. Jurnal Manajemen \& Strategi Akuntansi, 2(1): 1-32. Kewirausahaan, 6(1), 54-71.

Warren, J. M., Warren, C. S., \& Duchac, J. E. (2013). Principles of Accounting, 24th Edition.

Singapura: Cengage Learning Asia Pte Ltd. 